\title{
Invitation of Hemlock
}

\author{
Ahmed S* \\ Independent scholar, Bangladesh
}

*Corresponding author: Sayed Ahmed, 32/2 B B Road, Narayanganj 1400, Bangladesh, Tel: +881707219556; Email: ar.sayedahmed@gmail.com

\section{Book Review}

Volume 3 Issue 4

Received Date: October 19, 2020

Published Date: October 30, 2020

DOI: $10.23880 /$ phij-16000156

\section{Book Review}

This is the first history based novel of writer and diplomat Sujan Debnath. The foremost personality of this book is the great philosopher Socrates of antique Greece, who forfeited his whole lifespan to free humanity with the 'Love of knowledge'. Readers may hardly find it difficult that who is missing in this novel from ancient golden era of Greece? Father of medicine, Hippocrates; father of history, Herodotus; great masters of tragedy like Euripides, Sophocles and Aristophanes, renown sculptor Phidias, distinctive architects like Ictinus and Callicrates, urban planner Hippodamus of Miletus and his the eminent disciples like Plato, Phaedo, Crito etc. The most important thing we discovered here how women were treated in that time. The great leader Pericles got inspiration from free will thinker like Aspasia. She was an unsung figure in history. Again, we always thought conventionally that Xantippe was a quarrelsome lady while the author depicted her as loveable from inside but harsh in appearance to quench the thirst of livelihood and reality. The novel will give any reader surely a decent idea about ancient Greek Islands. The cultural inventions like drama, mythology, ethos, fine art, municipal society, disgrace in social order etc. were perfectly reflected over the lifespan of Socrates in this book. By depicting every single characteristics of particular epoch, the novelist molded an effective fictional biosphere for any reader to ease the delicate realm of the whole ancient Greek world. There, Athens was utmost influential, richest and multiethnic city. For instance, the slavery trade of Agora, maritime power with its nautical machineries, plague epidemic and their irreplaceable governing system of Democracy-all was inscribed here vividly. The writer prepared an amazing memorandum also; such governing system turned them united and invincible against all the dangers posed by mighty Persian Empire; while usually these Greek islands had clashes between. The readers might get to know about the architectural gem of temple Parthenon in Acropolis and why it was molded after the principles of Pythagoras's golden ratio bearing the inheritance of Thales who fetched trigonometry from Egypt. Parthenon was not an edifice only; it was more than poetry, written by stone. How the ancient Greek artists dignified the astral azimuth, temple orientation, allocated stratagem for respective divinity and precast cosmology in these temple forms: all were unknown to most of the readers. Two architects, Ictinus and Callicrates worked really hard with their supervisor; sculptor Phidias to express clandestine symbolism by implementing innovative engineering, which was described dramatically by author. There were also controversies for funding of such huge project, as it was not an easy decision to build such mega structure with the money of Delian league. This ignited a bloodshed costly war against Peloponnesian states lead by Sparta. This war brought a plague epidemic and for the consequence, great leader of Athenian golden age, Pericles died. The scenic description of Pnyx hill as seat of democracy, oracle temple at Delphi, symposium culture, amphitheater, Olympic sports event- all were incorporated in this novel with appropriate assembly of various plots which require admiration, specially a writer who is writing for the first time. Moreover, the citizen law, marriage law, women empowerment during $5^{\text {th }}$ and $4^{\text {th }}$ century BC was really astonishing for researchers to know. Also author provided information in this historical based novel that the ancient dramatists were effective enough to mislead audience, for example Aristophanes wrote a parody about Socrates named 'the cloud'. This play narrates how Socrates is misleading the youth of Athens, why elderly populaces hate him and how he tries to chasten well established norms and values by criticizing their faiths as well as being disrespectful to God and Goddesses. For such kind of offence, the great philosopher, Socrates brought into a charge and was punished for death sentence that all we know, drinking Hemlock leave poison in the prison. That's how the novel ends. None of these characters were imagery, again the author also did not wrote anything boring which will let any reader to get irritated for just like being taught in history class. Definitely it's a reading of pleasure. Actually, 
a bunch of enlightened personalities from one and only civilization of Europe were given vivid life in this novel. The author created blood and flesh over the historical skeleton. As it is first novel in Bangla language about Greece and this great civilization was not presented in this way before, thus this could be a great resource for the scholars for upcoming days.

The author is really successful to create a harmony and the way this novel was progressed, any inquisitive mind might think that he or she is also a witness of the foundation time of human civilization in continental Europe. The accomplishment this novel posed with is, the way history was narrated as story. It could be considered as both credit and merit of novelist. Finally, it is a must read book about classical Greece and its philosophy in the sphere of Bangla language population of the world who already got exhausted amidst the scholarly, foreign discourses over such resource. And truly, it is also pleasant for general Bangla speaking readers, as it provides rare opportunity to know a culture of far distance with language of their own. 